\title{
Credit Constraint and Technical Efficiency of Smallholder Cassava Farmers in Osun State, Nigeria
}

\author{
Ayodeji Damilola KEHINDE*, Muyiwa Sunday OLATIDOYE \\ Obafemi Awolowo University, Faculty of Agriculture, Department of Agricultural Economics, Ile Ife, Osun State, Nigeria
}

\begin{abstract}
This study investigated the effect of credit constraint on technical efficiency of smallholder cassava farmers in Osun State, Nigeria. A structured questionnaire was used to collect primary data from 200 smallholder cassava farmers using a multi-stage sampling procedure. Data collected were analysed using descriptive statistics and stochastic frontier model. Results from the descriptive statistics showed that majority (81\%) of the cassava farmers were male with the mean age of $44.1( \pm 14.9)$ years. About $86 \%$ of the respondents were married with mean household size of $6.9( \pm 3.5)$ persons. The results further revealed that $65 \%$ of the farmers were credit constrained. Results obtained from the stochastic frontier model showed that smallholder cassava farmers had an average technical efficiency of $73.6 \%$ in cassava production. The empirical results from the frontier model showed that man-day of labour significantly influence the technical efficiency of smallholder cassava farmers in Osun State. However, access to credit, amount of credit constrained and years of education were the major sources of technical inefficiencies among smallholder cassava farmers. The study concluded that majority of smallholder cassava farmers were credit constrained, as the amount of credit they received is not sufficient for their production which subsequently affected their technical efficiency. It was recommended that organizations giving agricultural credits to cassava farmers should enhance their credit services. This will assist smallholder cassava farmers to improve their technical efficiency.
\end{abstract}

Key words: credit constraint, technical efficiency, cassava, smallholder farmers

\section{INTRODUCTION}

Nigeria is currently the largest producer of cassava (Manihot esculenta Crantz) in the World with an annual production of about 59 million tonnes (FAOSTAT 2019). Cassava production has contributed to the economic development of Nigeria and created more employment among the people of the country (Ogunleye et al., 2017). However, cassava production is largely dominated by smallholder farmers and domicile in the rural communities where little or no credit service is available to them (Safullahi and Haruna, 2012). Access to credit has a perceptual significance in sustenance and improvement of cassava production, especially among smallholder farmers in Nigeria, particularly Osun State. Despite the importance of credit to cassava production, cassava farmers received amount lesser than the required amount of credit for their production. Thus, they are credit constrained in terms of quantity.

With farmers being credit constrained, it is impossible for them to purchase needed resources for production, not to mention maximizing output from given resources or minimizing the resources required to producing a certain amount of output. Hence, the combination of inputs used and amount of output produced by such farmers will be below optimal level. Consequently, credit constraint has both direct and indirect effects on cassava production. Directly, it affects the purchasing power of cassava farmers to make investments on their cassava farms. It indirectly affects the farmers' combination of resources required for producing output of cassava, which affects the technical 
efficiency of the farmers (Guirkinger and Boucher, 2008). Thus, prevalence of credit constraints among cassava farmers will reduce cassava production in Nigeria through its impact on technical efficiency of farmers. This therefore suggests that investigating the effect of credit constraint on technical efficiency will present an interesting policy implication, that offering credit to smallholder cassava farmers is one of the effective approaches to allow farmers to think deep and improve on their technical efficiency.

However, several studies on credit constraints had largely focused on production output, gross margin or profit, income, welfare, farm productivity and investments (Foltz, 2004; Petrick, 2005; Blancard et al., 2006; Komicha and Ohlmer, 2006; Guirkingern and Boucher, 2008; Omonona et al., 2008). Empirical studies on effect of credit constraints on technical efficiency are still limited, particularly in Nigeria. Consequently, the study investigated effect of credit constraints on technical efficiency of smallholder cassava farmers in Osun State. Specifically, this paper has four main objectives; (1) describe the socio-economic characteristics of the smallholder cassava farmers; (2) profile credit constraint status of smallholder cassava farmers; (3) determine the technical efficiency of smallholder cassava farmers; (4) determine the effect of credit constraint on technical efficiency of smallholder cassava farmers.

\section{MATERIAL AND METHODS}

\section{Study area}

The study was conducted in Osun State, Nigeria. Osun State lies on latitude $7^{\circ} 30^{\prime} \mathrm{N}$ of the equator and longitude $4^{\circ} 30^{\prime} \mathrm{E}$ of the Greenwich meridian and on a land area of about 9,251 $\mathrm{km}^{2}$. Osun State shares boundaries with Kwara State in the North, Oyo State in the West, Ogun State in the South, Ondo and Ekiti States in the East. The provisional 2006 population census result put the population of Osun State at 3,423,535 (NPC, 2007). The State has 2 distinct climatic seasons, namely the dry and wet seasons. The natural vegetation comprises moist evergreen and semi-evergreen forest and secondary forest, with mean annual rainfall ranging between 1400 to $2000 \mathrm{~mm}$ while mean annual temperature ranges between $25^{\circ} \mathrm{C}$ to $27^{\circ} \mathrm{C}$ thereby providing a conducive climate for growing most tropical crops. Crops grown in the State include cassava, cocoa, oil palm tree, African walnut, palm kernel, citrus, mango and arable crops which include yam, potatoes, cocoyam, maize, sugar cane, vegetables, tomatoes, pepper, and okra. Sheep, goat and poultry rearing are also predominant in the study area.

\section{Sampling procedure}

Multi-stage sampling procedure was employed to select respondents for the study. The first stage involved a purposive sampling of four Local Government Areas (LGAs) in the State because of their prominent involvement in cassava production in the State. The LGAs selected includes Ife East,
Ife Central, Ife North and Ife South LGAs. In the second-stage, simple random technique was used to select five communities from each LGA. Finally, at the third-stage, simple random technique was used to select 10 cassava farmers from each community. In total, 200 cassava farmers were selected for the study.

\section{Analytical technique}

Descriptive statistics and stochastic frontier model were used to analyse the collected data.

\section{Descriptive statistics}

Descriptive statistics (mean and percentages) were used to describe the socioeconomic characteristics of smallholder cassava farmers.

\section{Stochastic frontier model}

Stochastic frontier model was used to estimate the technical efficiency of smallholder cassava farmers and the effect of credit constraint on the technical efficiency of smallholder cassava farmers. Battese and Coelli (1995), Ajibefun (2002) and Ojo (2004) stated that the stochastic frontier model has an advantage of allowing concurrent estimation of individual technical efficiency as well as determinants of source of technical inefficiencies. The stochastic frontier production postulates the existence of technical inefficiencies of production for farmers involved in production of certain crop. Total production of $\mathrm{i}^{\text {th }}$ farmer is well-defined as the frontier minus the inefficiency (Dhawan and Jochumen, 2012). The model decomposes the disturbance term into measurement error and inefficiency effect. This study estimated the parameters in the model using the maximum likelihood approach.

The basic stochastic production frontier is modelled as follows:

$$
R i=f(x i j ; \beta) e(\emptyset i-\eta i), u i=\emptyset_{i}-\eta i \text { and } i=1,2,3, N ; j=1,2, \ldots J
$$

where $R i$ denotes the output of the $\mathrm{i}^{\text {th }}$ cassava farmer, $(x i j)$ represents a vector of inputs, and $\beta$ is a vector of the unknown parameters to be estimated. Equation (1) is not a linearized function. The equation was then linearized by taking the natural logarithm of both sides to give equation (2)

$$
\ln R i=\alpha+\sum J j=1 \beta j \ln x i j+\varnothing i-\eta i, u i=\varnothing i-\eta i . .
$$

where $\emptyset_{i}$ is the systematic random error that accounts for measurement error and other factors that are not under the control of the farmers, and $\eta i$ denotes the asymmetric nonnegative random error component that measures technical inefficiency effects. The systematic random error variable is assumed to be independently and normally distributed with zero mean and variance $\sigma 2$ (Coelli, 1995).

The empirical Cobb-Douglas stochastic production function model is specified as follows: 
$\ln \mathrm{Y}=\mathrm{b}_{\mathrm{o}}+\mathrm{b}_{1} \ln \mathrm{X}_{1 \mathrm{i}}+\mathrm{b}_{2} \ln \mathrm{X}_{2 \mathrm{i}}+\mathrm{b}_{3} \ln \mathrm{X}_{3 \mathrm{i}}\left(\mathrm{V}_{\mathrm{i}}-\mathrm{U}_{\mathrm{i}}\right)$

where $\mathrm{Y}=$ the natural logarithm of output of cassava $(\mathrm{kg})$

The explanatory variables are: $X_{1}=$ farm size (ha); $X_{2}=$ agrochemical (litres); $\mathrm{X}_{3}=$ labour (man-day); $\mathrm{V}_{\mathrm{i}}=$ random errors outside the farmers control, and $\mathrm{U}_{\mathrm{i}}=$ technical inefficiency effects.

The determinant of technical inefficiency $\left(\mathrm{U}_{\mathrm{i}}\right)$ is defined by:
$\mathrm{U}_{\mathrm{i}}=\mathrm{d}_{0}+\mathrm{d}_{1} \mathrm{Z}_{1}+\mathrm{d}_{2} \mathrm{Z}_{2}+\mathrm{d}_{3} \mathrm{Z}_{3}+\mathrm{d}_{4} \mathrm{Z}_{4}+\mathrm{d}_{5} \mathrm{Z}_{5}$

where: $\mathrm{U}_{\mathrm{i}}=$ inefficiency effects

The explanatory variables are: $Z_{1}=$ access to credit (Yes=1, $\mathrm{No}=0) ; Z_{2}=$ credit constraint status $(\mathrm{Yes}=1, \mathrm{No}=0) ; Z_{3}=$ Years of education (Years); $Z_{4}=$ amount of credit constraint $(\mathbb{N}) ; Z_{5}$ $=$ Numbers of credit sources (actual numbers).

The rationale behind the inclusion of the explanatory variables in the model was based on the review of literature (Table 1). These explanatory variables are expected to influence the technical efficiency of cassava farmers.

Table1: Description of variables

\begin{tabular}{|l|l|c|l|}
\hline Variables & Units & Expected signs & Studies \\
\hline Farm size & Hectares & + & Adewuyi et al. (2013) \\
\hline Agrochemical & Litres & + & Idiong (2006) \\
\hline Labour & Person-day & + & Ogunleye et al. (2017) \\
\hline Access to credit & Yes=1, No=0 & + & Komicha and Ohlmer (2006) \\
\hline Amount of credit constrained & Naira & - & $\begin{array}{l}\text { Komicha and Ohlmer (2006), Mehmood et } \\
\text { al. (2017) }\end{array}$ \\
\hline Education & Years & + & Ogunleye et al. (2017) \\
\hline Credit constraint status & Yes=1, No=0 & - & $\begin{array}{l}\text { Komicha and Ohlmer (2006), Mehmood et } \\
\text { al. (2017) }\end{array}$ \\
\hline Number of credit sources & $\begin{array}{l}\text { Actual number of credit } \\
\text { source }\end{array}$ & + & Awejire and Rahman (2014) \\
\hline
\end{tabular}

\section{RESULTS AND DISCUSSIONS}

\section{Socio economics characteristics of smallholder cassava farmers}

Socio-economic characteristics of smallholder cassava farmers are presented in Table 2. Majority (81\%) of the respondents are male. This indicates that male farmers dominatecassava production. The mean age of the respondents is approximately 44 years. In this case, it can be affirmed that most cassava producers are young and economically active. Majority (86\%) of the respondents are married. This implies that cassava production is dominated by married people. About $71 \%$ of the respondents have formal education. This implies that most of the cassava farmers had formal education. The mean household size is approximately 7 persons. This implies that the farmers have enough family labour to assist in cassava production. About $23 \%$ of the respondents receive credit from cooperatives. Majority (71\%) of the respondents have access to credit. This reveals that most of the cassava farmers have access to credit for their production.

\section{Credit constraint status of smallholder cassava farmers}

The profile of amount of credit needed for production, amount of credit applied for, amount of credit received, and credit constraint status of smallholder cassava farmers are
Table 2: Socio-economic characteristics of smallholder cassava farmers

\begin{tabular}{|l|l|}
\hline Variables & Cassava Farmers \\
\hline Age (years) & $44.13( \pm 14.89)$ \\
\hline Male $(\%)$ & 81 \\
\hline Married $(\%)$ & 86 \\
\hline Formal education $(\%)$ & 71 \\
\hline Household size & $6.89( \pm 3.51)$ \\
\hline Access to credit & 71 \\
\hline Cooperative $(\%)$ & 23 \\
\hline
\end{tabular}

Source: Field survey (2019)

presented in Table 3. The average amount of credit needed for cassava production is $\mathrm{N} 860$ 935. The mean amount of credit applied for and credit received are 480601 and $\$ 174$ 740, respectively, thus the amount of credit constraint is 305 581. This implies that the farmers receive amount less than the actual amount of credit demanded for their cassava production. Overall, about $65 \%$ of the respondents were credit constrained. This shows that majority of the farmers are credit constrained and credit constraints could have detrimental effect on their technical efficiency. 
Table 3: Credit constraint status of smallholder farmers

\begin{tabular}{|l|l|}
\hline Variables & Cassava farmers \\
\hline Production needs $(\mathbb{})$ & $860935( \pm 464737)$ \\
\hline Amount applied ( $)$ & $480601( \pm 245145)$ \\
\hline Amount received ( $)$ & $174740( \pm 125925)$ \\
\hline Amount constrained (N) & $305861( \pm 115890)$ \\
\hline Credit constraint status (\%) (yes) & 65 \\
\hline
\end{tabular}

Source: Field survey, 2019

\section{Technical efficiency of smallholder cassava farmers}

Technical efficiency scores generated from the stochastic frontier model are presented in Table 4. The technical efficiency scores ranged from $24 \%$ to $91 \%$ with a mean score of $73.6 \%$.

Table 4: Technical efficiency of smallholder cassava farmers

\begin{tabular}{|l|l|l|}
\hline Technical efficiency & Frequency & Percentage \\
\hline $0.20-0.39$ & 9 & 9 \\
\hline $0.40-0.59$ & 7 & 7 \\
\hline $0.60-0.79$ & 33 & 33 \\
\hline $0.80-0.99$ & 51 & 51 \\
\hline Total & 100 & 100.0 \\
\hline $\begin{array}{l}\text { Minimum technical } \\
\text { efficiency }\end{array}$ & 0.24 & \\
\hline $\begin{array}{l}\text { Maximum technical } \\
\text { efficiency }\end{array}$ & 0.91 & \\
\hline Mean technical efficiency & 0.736 & \\
\hline Standard deviation & 0.372 & \\
\hline
\end{tabular}

Source: Field survey (2019)
By implication, this suggests that an average smallholder cassava farmer lost $26.4 \%$ of their output as a result of technical inefficiency. This implies that cassava farmers need to improve their optimization of resource by $26.4 \%$ in order to operate at full efficiency level.

\section{Effect of credit constraint on technical efficiency of cassava farmers}

Table 5, shows that the sigma squared (2.437) is statistically significant at $1 \%$ probability level. This indicates the model is of good fit. The variance ratio, known as gamma $(\gamma) 0.954$, indicating $95.4 \%$ of the variation in output of the cassava farmers is due to inadequacy in technical efficiency. The generalized likelihood ratio test $(\lambda 2=0.546)$ is significant. This shows that stochastic frontier model has a significant improvement over the conventional production function. This justifies the use of stochastic frontier model to analyse the information in the dataset. The value of returns to scale (RTS), which is the sum of the coefficients of variables in the frontier model, was 4.973. This implies that smallholder cassava farmers are experiencing increasing return to scale. This further confirms that smallholder cassava farmers are yet to attain the optimum level of the combination of their resources. This is ascribed to the fact that the farmers are still producing in the first stage of production. This result collaborates the findings of Adeyemo et al. (2020). Among the factors included in the frontier model, the coefficient of labour was significant and positive. This implies that a percentage increase in manday of labour will increase technical efficiency of smallholder cassava farmers by $45.1 \%$. This is premised on the fact that cassava production is labour intensive and smallholder farmers seriously depend on physical labour for their production. As such, increase

Table 5: Effect of credit constraint on technical efficiency of cassava farmers

\begin{tabular}{|l|l|l|l|}
\hline Variables & Coefficient & Standard error & t-ratio \\
\hline Constant & $4.329^{* * *}$ & 0.131 & 33.043 \\
\hline Farm size & -0.022 & 0.026 & -0.856 \\
\hline Agrochemical & 0.215 & 0.145 & 1.480 \\
\hline Labour & $0.451^{\star * *}$ & 0.139 & 3.258 \\
\hline & & & \\
\hline Inefficiency parameter & & & -1.693 \\
\hline Access to credit & $-0.1638^{\star}$ & 0.968 & 1.509 \\
\hline Credit constraint status & 1.492 & 0.928 & -2.245 \\
\hline Year of education & $-0.3848^{\star *}$ & 1.714 & 1.871 \\
\hline Amount of credit constraint & $0.4283^{\star}$ & 2.289 & 0.549 \\
\hline Numbers of credit sources & 0.433 & 0.789 & \\
\hline Variance parameter & & & 3.419 \\
\hline Sigma-squared & $2.437^{* * *}$ & 0.713 & 55.92 \\
\hline Gamma & $0.954^{* * *}$ & 0.017 & \\
\hline Log likelihood function & -0.718 & & \\
\hline LR test & 0.546 & & \\
\hline Mean technical efficiency & 0.736 & & \\
\hline
\end{tabular}


in labour supply will increase cassava output. This finding is in line with the study conducted by Mensah and Brummer (2016) and Huy and Nguyen (2019).

However, in order to determine the sources of technical inefficiencies of smallholder cassava farmers, we considered the following variables; years of education, access to credit, credit constraint status, number of credit sources and amount of credit constrained in inefficiency model. Years of education was significant and negative; this implies that a percentage increase in year spent on education will increase technical efficiency of cassava farmers by $61.6 \%$. This is premised on the fact that investment in education empowers farmers with necessary knowledge and skills to utilize existing technologies which improves resource utilization and consequently, technical efficiency (Solís et al., 2009). Access to credit was significant and negative; this implies that a percentage increase in access to credit will increase technical efficiency of cassava farmers by $83.6 \%$. On the other hand, amount of credit constrained was significant and positive; this implies that a percentage increase in amount of credit constraint will decrease technical efficiency of cassava farmers by $57.2 \%$. The results agree with a prior expectation of the study. The relationship between credit access, amount of credit constrained could be explained by the fact that availability of credit facilitates acquisition of production inputs or existing technologies such as seeds, fertilizer, among others and consequently improves farmers' technical efficiency.

\section{CONCLUSION AND RECOMMENDATIONS}

The study investigated the effect of credit constraint on technical efficiency of smallholder cassava farmers in Osun State, Nigeria. A multistage sampling procedure was used to obtain data for the study. Descriptive statistics and stochastic frontier model were used to analyse the data collected. The results obtained from descriptive statistics revealed that $65 \%$ of the respondents are credit constrained. Results obtained from the stochastic frontier model showed that cassava farmers had an average technical efficiency of $73.6 \%$ in cassava production. Amount of credit constrained along with other socioeconomic factors such as access to credit and years of education were the major sources of technical inefficiencies among smallholder cassava farmers. This study concluded that credit constraint is among important variables affecting technical efficiency of smallholder cassava farmers. This suggests that policy strategies aimed at improving the technical efficiency of cassava farmers must consider their credit constraint status. However, organizations giving agricultural credits to cassava farmers should heighten their credit services. This will assist farmers to improve their technical efficiency.

\section{REFERENCES}

1. Abdul-kareem, M. M, \& Isgin, T. (2016). Technical efficiency of cassava production in the Savannah Zone of
Northern Ghana: Stochastic Frontier Analysis. Journal. of Biology and Healthcare Science, 6(20), 62-72.

2. Adewuyi, S. A., Agbonlahor, M. U., \& Oke, A. T. (2013). Technical efficiency analysis of cassava farmers in Ogun state, Nigeria. International Journal of Agriculture and Food Security, 4, 515-522.

3. Adeyemo, R., Kehinde, A. D., \& Oyenpemi, L.O. (2020). Assessing resource use efficiency and investment in cocoa enterprise: A case of Osun State, Nigeria. Agricultura, 113-114 (1-2), 260-269.

4. Ajibefun, A. I. (2002). "Analysis of policy issues on technical efficiency of small-scale farmers using the stochastic frontier production function: With application to Nigerian farmers". 13th Congress, Wageningen, The Netherlands, July 7-12, 2002 7015, International Farm Management Association.

5. Alvarez, A., \& Arias, C. (2004). Technical efficiency and farm size. Agricultural Economics, 30, 241-250.

6. Awejire, B., \& Rahman, S. (2014). Profitability and efficiency of cassava production at farm level in Delta State, Nigeria. International Journal of Agricultural Management, 3(4), 210-218.

7. Battese, G. E., \& Coelli, T.J. (1995). A model for technical inefficiency effects in a stochastic frontier production function for panel data. Empirical Economics, 20, 325-332.

8. Blancard, S., Boussemart, J., Briec, W., \& Kerstens, K. (2006). Short- and long-run credit constraints in French agriculture: A directional distance function framework using expenditure-constrained profit functions. American Journal of Agricultural Economics, 88(2), 351-364.

9. Coelli, T. J. (1995). Recent developments in frontier modelling and efficiency measurement. Australian Journal of Agricultural Economics, 39(3), 219-245.

10. Dhawan, R., \& Jochumen, P. (2012). Stochastic frontier production with error in variables. Working Papers 1999:007, Lund University, Department of Economics. Retrieved from: https://www.researchgate.net/ publication/5096417_Stochastic_Frontier_Production_Function_With_Errors-In-Variables

11. Farrell, M. J. (1957). The measurement of productive efficiency. Journal of the Royal Statistical Society, 120, 253-290.

12. Foltz, J. (2004). Credit market access and profitability in Tunisian agriculture. Agricultural Economics, 30, 229240.

13. Food and Agriculture Organization of the United Nations (FAOSTAT, 2019) FAOSTAT Statistical Database, Statistical division Rome.

14. Guirkinger, C., \& Boucher, S. R. (2008). Credit constraints and productivity in Peruvian agriculture. Agricultural Economics, 39(3), 295-308.

15. Huy, H. T., \& Nguyen, T. T. (2019). Cropland rental market and farm technical efficiency in rural Vietnam. Land Use Policy, 81, 408-423.

16. Idiong, I. C. (2006). Evaluation of technical, allocative and economic efficiencies in rice production systems in Cross River State, Nigeria, Unpublished Doctoral Dissertation Thesis, Department of Agricultural Economics, University of Calabar, Nigeria. 
17. Komicha, H. H., \& Öhlmer, B. (2006). Effect of credit constraints on production efficiency of farm households in South-eastern Ethiopia. Ethiopian Journal of Economics, 15(1), 1-34.

18. Mehmood, Y., Rong, K., Arshad, M., \& Bashir, M. K. (2017). Do liquid constraints influence the technical efficiency of wheat growers? Evidence from Punjab, Pakistan. The Journal of Animal \& Plant Sciences, 27(2), 667-679.

19. Mensah, A., \& Brümmer, B. (2016). Drivers of technical efficiency and technology gaps in Ghana's mango production sector: a stochastic metafrontier approach Amos. African Journal of Agricultural Resource Economics, 11(2), 101-117.

20. National Population Commission, (NPC) (2007). Population Figure. Federal Republic of Nigeria, Abuja. Retrieved from http://www.npc.gov.

21. Ogunleye, A. S., Adeyemo, R., Bamire, A. S., \& Binuiomote, S. O. (2014). Cassava production and technical efficiency in Ayedaade Local Government Area of Osun State, Nigeria. Elixir International Journal of Agriculture, 71, 24465-24468.

22. Ogunleye, A. S., Adeyemo, R., Bamire, A. S., \& Kehinde, A. D. (2017). Assessment of profitability and efficiency of cassava production among government and non-government assisted farmers association in Osun State, Nigeria. African Journal of Rural Development, 2(2), 225-233.

23. Ojo, S. O. (2004). Improving labour productivity and technical efficiency in food crop production. A panacea for poverty reduction in Nigeria. Journal of Food and Agricultural Environment, 2(2),227-231.

24. Omonona, B. T., Akinterinwa, A. T., \& Awoyinka, Y. A. (2008). Credit constraint and output supply of Cowan farmers in Oyo state, Nigeria. European Journal of Social Sciences, 6(3), 382-390.

25. Petrick, M. (2005). Empirical measurement of credit rationing in agriculture: A methodological survey. $A g$ ricultural Economics, 33(2), 191-203.

26. Saifullahi, S. I., \& Haruna, M. A. (2012). An analysis of farmers' access to formal credit in the rural areas of Nigeria. African Journal of Agricultural Research, 7(47), 6249-6253.

27. Solı's, D., Bravo-Ureta, B.E., \& Quiroga, R.E. (2009). Technical efficiency among peasant farmers participating in natural resource management programmes in Central America. Journal of Agricultural Economics, 60(1), 202-219. 


\section{Kreditna sposobnost in tehnična učinkovitost manjših pridelovalcev kasave v državi Osun State, Nigeria}

\section{IZVLEČEK}

Cilj raziskave je bil preučiti vpliv kreditne sposobnosti na tehnično učinkovitost manjših pridelovalcev kasave $\mathrm{v}$ državi Osun v Nigeriji. Osnovni podatki za 200 kmetov pridelovalcev kasave so bili zbrani s pomočjo strukturiranega vprašalnika z večstopenjskim vzorčenjem. Zbrani podatki so bili analizirani z uporabo opisne statistike in stohastičnega modela meje. Rezultati opisne statistike so pokazali, da je večina (81\%) pridelovalcev kasave moškega spola, starih v povprečju 44,1 ( $\pm 14,9)$ let. Približno $86 \%$ anketirancev je poročenih in živijo v gospodinjstvih s povprečno $6,9( \pm 3,5)$ družinskimi člani. Rezultati raziskave so nadalje pokazali, da je $65 \%$ anketiranih kreditno omejenih ali nesposobnih. Rezultati, pridobljeni s pomočjo stohastičnega modela meje, so pokazali, da so imeli pridelovalci kasave v povprečju 73,6-odstotno tehnično učinkovitost pri proizvodnji kasave. Dejavniki kot so dostop do posojila, omejena vrednost posojila in stopnja izobrazbe so v največji meri določali tehnično učinkovitost pridelovalcev kasave. V raziskavi so zaključili, da je večina pridelovalcev kasave kreditno omejenih ali nesposobnih, saj znesek prejetega posojila ne zadostuje za financiranje proizvodnje, kar nadalje vpliva na tehnično učinkovitost. Na osnovi tega so avtorji priporočili, da organizacije, ki dajejo kmetijska posojila pridelovalcem kasave, povečajo svoje kreditne storitve. Na ta način bodo pridelovalci kasave lahko izboljšali tehnično učinkovitost.

Ključne besede: kreditna sposobnost, tehnična učinkovitost, kasava, mali kmetje 